\title{
Investigating a proper housing model with an urban design approach (case location: third district of Kabul city, Karteh- Mamourin)
}

\author{
Safiullah Sekandari. Sanaz Litkoohi, Sayed Ali Iqbal
}

\begin{abstract}
:
Increasing population in cities due to various reasons such as migration from rural to urban areas, insecurity in areas, civil wars, lack of facilities and access such as health centres, technical schools, universities, industrial development and many other issues. It has caused the density and increase of population in cities to be higher than before, and this increase in population has caused a shortage of housing in the community. this is especially true in developing countries such as Afghanistan, where the war is not over. the present study based on suitable housing with emphasis on urban design approach for citizens in the third district of Kabul, includes the karteh-mamourin and has tried to examine the pros and cons of different types of housing and answer the question that these housing what facilities do they have access to from an urban point of view and what is the level of satisfaction with these houses? Quantitative research method has been used for this purpose. to examine the research hypotheses, considering the population of the statistical population and the available facilities and capacities, 150 questionnaires have been considered. Using spss statistical software, many topics of respondents and analysis of hypotheses have been examined and finally, after the analysis, the final result has been obtained. Hierarchical analysis (Ahp) method has also been used in this research. The final result of this research shows that in order to provide a suitable housing model in terms of urban design for the residents of the study area, the criteria and indicators of the physical-spatial structure of the city are the most important.
\end{abstract}

Keywords: Hierarchical Analysis, AHP, Proper Housing, Karteh-Mamourin), Analysis.

Safiullah, S., Sanaz, L., \& Sayed Ali, I. (2021). Investigating a proper housing model with an urban design approach (Case location: Third district of Kabul city, karteh-mamourin). Journal of Urban Planning and Architecture, 2(3), 9-26. 


\section{برر سى الكَى مسكن مناسب با رويكرد طراحى شهرى(مكان موردى: ناحيه سوم

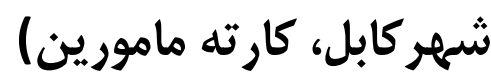 \\ صفى الله سكندرى'، ساناز ليتكوهى '، سيدعلى اقبال مارئ ا-ماستر طراحى شهرى دانشگاه يِام نور مركز كابل

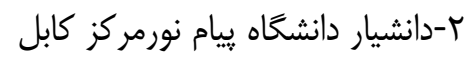 \\ r-استاد دييارتنمت طراحى شهرى دانشخاه ييام نور مركز كابل}

جكيده

افزايش جمعيت در شهرها به علت هاى مختلف مانند، مهاجرت از روستاها به شهرها، نامنى مناطق، جنكَهاى

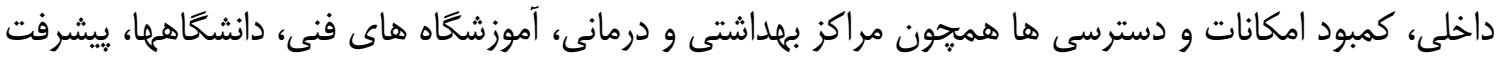

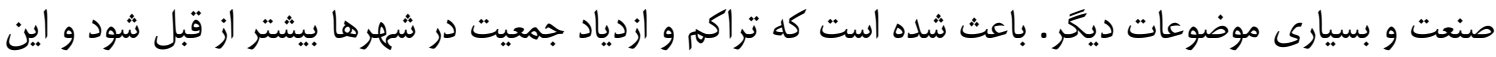
ازدياد جمعيت باعث كمبود مسكن در اجتماع را بوجود آورد. اين موضوع در كشورهاى در حال توسعه مانند افغانستان كه جنگ هنوز در آن تمام نشده است بيشتر احساس مى گردد. تحقيق حاضر بر مبناى مسكن مناسب

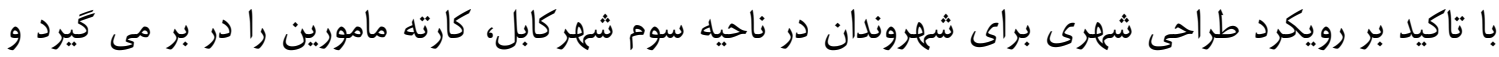
كوشيده است كه نقاط مثبت و منفى انواع مسكن را به بررسى بحيرد و به اين سوال ياسخ دهد كه اين مسكن ها از نظر شهرى به كدام امكانات دسترسى دارند و ميزان رضايتمندى-از اين مسكن ها جگگونه است. به اين منظور از روش تحقيق كمى استفاده شده است. براى بررسى فرضيه هاى تحقيق با در نظر داشت نفوس جامعه آمارى و و امكانات و ظرفيت هاى موجود به تعداد •هاعدد يرسشنامه در نظر گرفته شده است. با استفاده از نرم افزار آمارى لرى

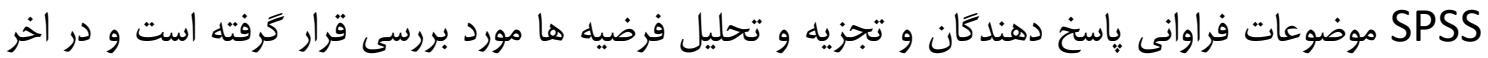
بعد از اتمام تجزيه و تحليل، نتيجه نهايى بدست آمده است. همجنين در اين تحقيق از روش تحليل سلسله

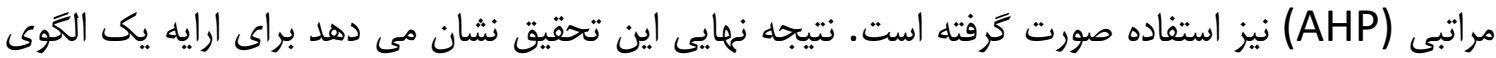
مسكن مناسب از نظر طراحى شهرى براى ساكنين محدوده مورد مطالعه بيشترين اهميت را معيار و شاخصهاى ساختار كالبدى-فضايى شهرى دارا مى باشد.

وازههاى كليدى: تحليل سلسله مراتبى، AHP، مسكن مناسب، كارته مامورين، تجزيه و تحليل.

استناد: سكندرى، ص. ا، ليتكوهى، س و اقبال، س. ع. (••(1F). بررسى الخَوى مسكن مناسب با رويكرد طراحى شهرى(مكان

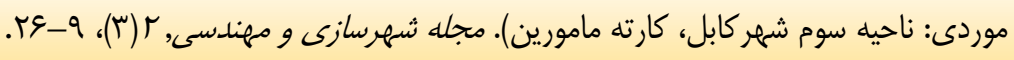




\section{مقدمه}

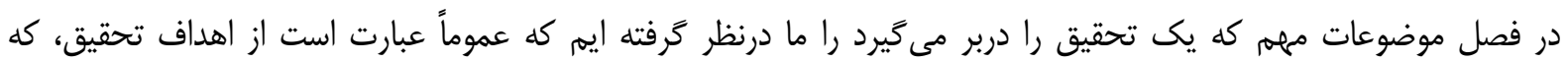
هدف اساسى و انكيزهاى كه محقق را واداشته است كه عنوان و مكان مورد نظر را در نظر گرفته است دربرمى مئيرد. سؤالات اساسى تحقيق، كه يك بخش مهمم تحقيق را تشكيل مى دهد و سوالات تحقيق بادرنظرداشت موضوعاتى كه از تحقيق ما درآن شامل مى شود و كوشش گرديده است كه مهمترين موضوعاتى كه در اين تحقيق را داشته است در تجزيه و تحليل آن بتواند

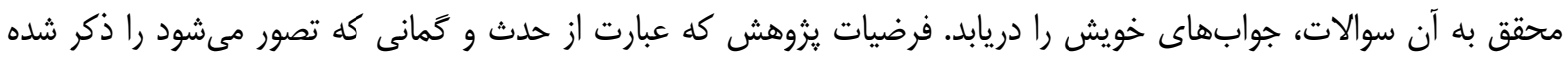
است، و اين همان حدث و كمان هايى است كه ارتباط مستقيم با سوالات تحقيق را دارا مىباشد و در اثبات و رد فرضيات در فصل هاى بعدى بيشتر و بهتر مورد بررسى قرار گرفته است و در اين فصل بطور خلاصه يادبود گرديده است كه كدام موضوع مورد تجزيه و تحليل در بخش فرضيات يُوهش شامل مىباشد. اهميت و ضرورت تحقيق كه كدام ضرورت احساس مى شعود اين تحقيق روى دست كرفته شده است و در اين يزوهش به اهميت كه ضرورت ايجاب نموده است در زمينه اين يزوهش

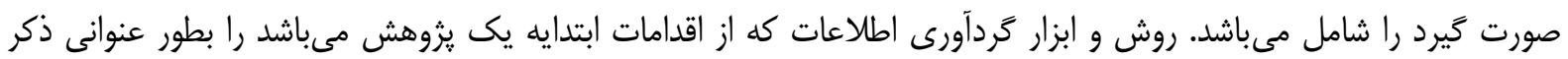
كرديده است و هم جنان روش تحقيق كه توسط آن بتوانيم تجزيه و تحليل داده هاى تحقيق را دريافت نمائيم اصل يك يزوهش را تشكيل مىدهد را نيز آورده شده است، نوآورى تحقيق، قلمرو تحقيق كه بطور خلاصه و معين در اين فصل ذكر

\section{بيان مسئله:}

رشد تدريجى انسان ها، انكشافات و توسعه هاى فكرى، تغير شيوه توليد و معشيت مردم باعث ايجاد شيوه هاى نوين در زندكى انسان ها شده است. در دنياى كنونى امروز مسكن و يا سر يناه يكى از نيازهاى ضرورى و اساسى مادى انسان قلمـداد مسى شود و به لحاظ زيستى،اجتماعى و اقتصادى نقش خطيرى در بقاى زندگى انسان هاى قرن حاضـر دارد. مسكن يك مكان فيزيكى است و به عنوان سريناه و نياز اوليه و اساسى خانوار به حساب مى آيد و در اين سريناه برخى ازنيازهاى اوليه فرد مانند

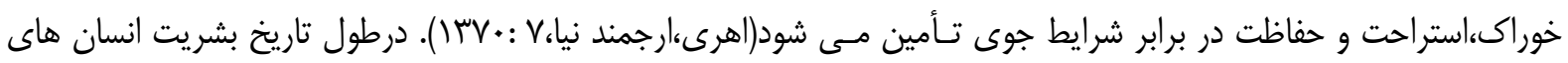

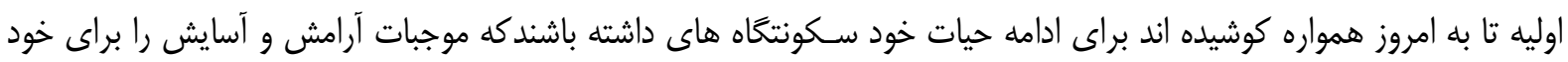

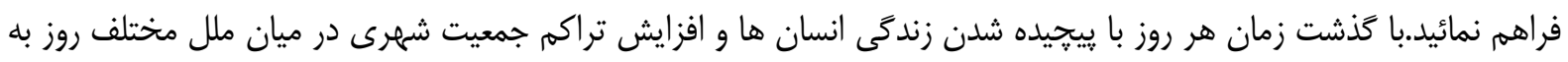

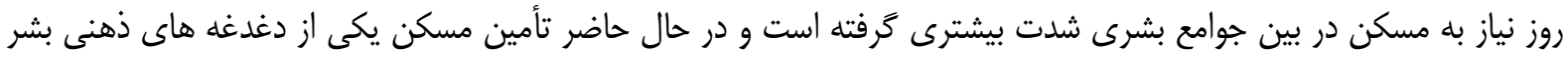
تلقى مى شود. با ييمودن اين مسير طولانى، خواست ها در مورد مسكن و بود و باش نيز تاثير كذار بوده است. رهبران شيرازه

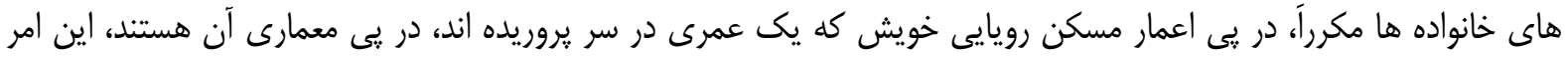
يك كار ير از خلاقيت و خالش ها براى معماران هم شده است. معماران به ناجار خود را با اين تغييرات شرايط برابر ساخته، اين موضوع سبب شده تا از كوى از ابتلاعات كَذشته و يك الحَوى از مسكن را كه جوابكو ساكنين باشد ايجاد نمايند. اين ايده ها ها هم

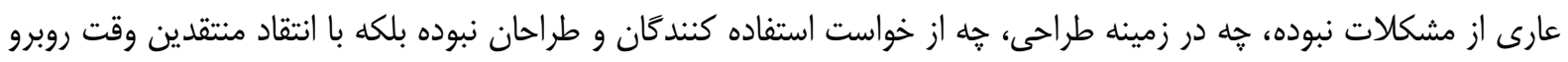
نيز شده است. در سال هاى اوليه قرن بيسته،كروهى از متفكران ارويايى تلاش كردند مسايل شهرى را بدون احتياج به تغييرات اساسى اجتماعى حل نمايند. تونى كارنيه شروع به مطالعه شهر صنعتى نمود و نكته قابل توجه در مورد الخوى مسكن شهر صنعتى گارنيه، ييش بينى بلوى هاى إيارتمانى مجهز به خدمات عمومى بود كه منعكس كننده نظريه مجتمع هاى مسكونى 
مجهز به خدمات عمومى اوليه است. علاوه بر اين، تفكرات لوكوربوزيه نيز تاثير فراوانى بر تكامل مجتمع هاى مسكونى كذاشته است. به عقيده او، الحَوى مسكن كم طبقه كه به معنى زندگى در خانه و زمين شخصى بود، باعث هدر رفتن زمين مى شد، در حاليكه زندگى در ساختمان هاى بلندمرتبه اى كه در ميان فضاى سبز يراكنده شده اند، راه حلى كاراتر و بهتر در برنامه ريزى

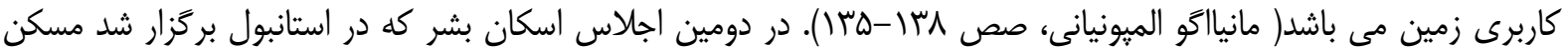
را از نغاه ابعاد و مفهوم קجنين تعريف نموده اند: سريناه مناسب تنها به معنى وجود يكى سقف بالاى سر هر شخص نيست؛ سريناه

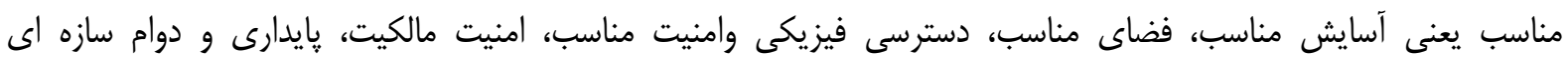

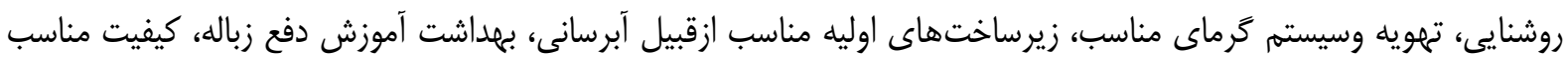
زيست محيطى، عوامل بهداشتى مناسب، مكان مناسب وقابل دسترسى ازنظر كار وتسهيلات اوليه است كه همه اين موارد بايد باتوجه به استطاعت مردم تامين شود (عو199).

\section{ييشينه يزوهش:}

\section{ي بيشينه يزوهش هاى داخلى}

سيد ضياء حسينى در كتاب "مقدمه اى بر تاريخ معمارى و شهرسازى افغانستان" درباره انواع مختلف معمارى و ساخت اماكن در افغانستان و جهان اشاره اى كرده است، شهرسازى يا ساخت مسكن يكى از اساسىترين سياستهاى دولتها مىتواند باشد جها بسا دولتى با سياست نادرست در بحث مسكن زير سوال رود و دولتى همانند برزيل با رشد صنعت مسكن هم تقاضاى كار را راس

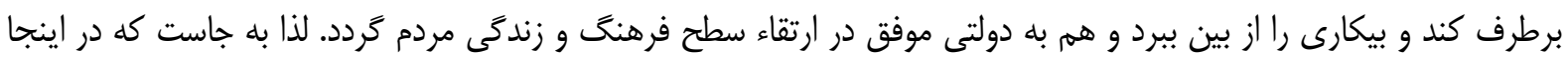

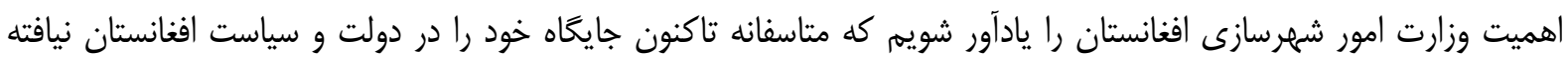
است و هنوز هم از قابليت هاو تاثير زارى زياد آن بىخبر هستند (حسينى، سيد ضيا، (وسا، انتشارات خراسان، كابل).

\section{بيشينه يزوهش هاى خارجى}

رستم صابرى فر، در مقاله اى تحت عنوان: بررسى شاخص هاى الحوى مسكن مناسب از منظر ساكنين گروه هاى حاشيه نشين شهر مشهد را مورد بررسى و ارزيابى قرار داده است كه در اين تحقيق، شاخص هاى الكوى مسكن مناسب از منظر ساكنين حاشيه نشين شهرى در مشهر مورد بحث قرار گرفته است به اين منظور، از روش تحقيق توصيفى و تحليلى بهره بردارى شده و

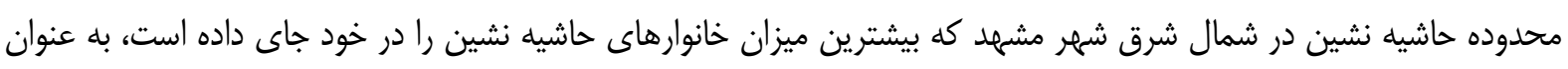

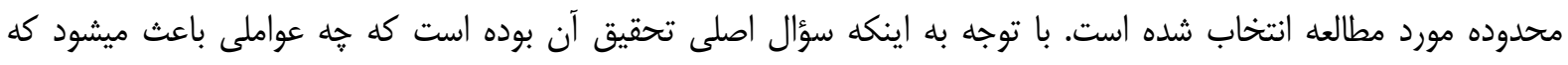

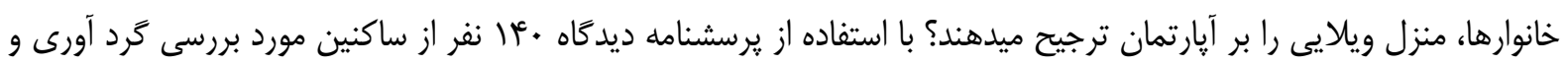

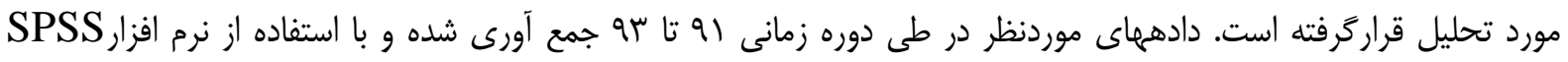
تجزيه و تحليل كرديد. نتايج نشان داد متغيرهايى نظير نحوه تملك، تحصيلات، سال خريد واحد مسكونى و سن از جمله عواملى

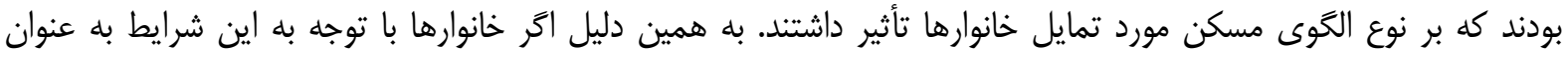

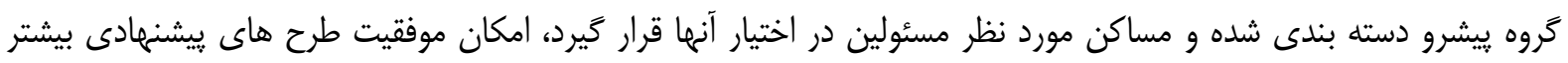

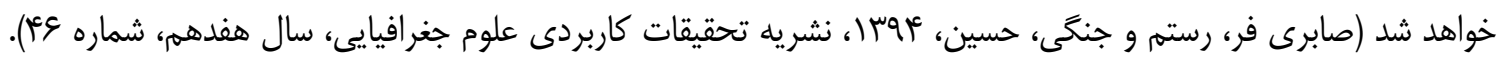


اهداف تحقيق:

حالت فعلى مسكن و محيط مرتبط به سكونت كاه در شرايط كنونى مانند يك مسئله حاد شده است كه نمىتوان يك پاسخ مشخصى براى حل آن ارائه كرد، از تجارب كذشته ها در كشورهاى جهان اول و دوم مىتوان نمونه ى را برداشت و به صورت تك محورى عمل و نتايج آن را متخصصانه داورى نموده و با بعد نوآورانه ييشكش عام مردم نمود، در اين صورت بايد بهايد كه

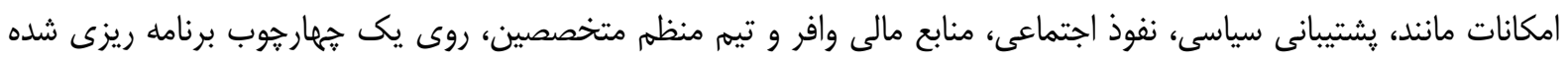

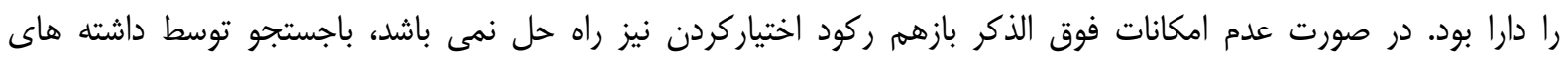

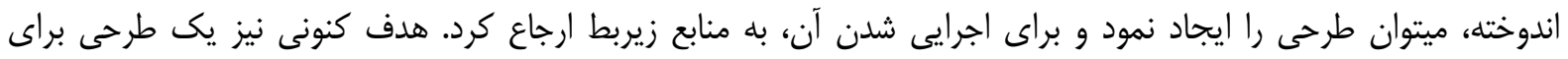

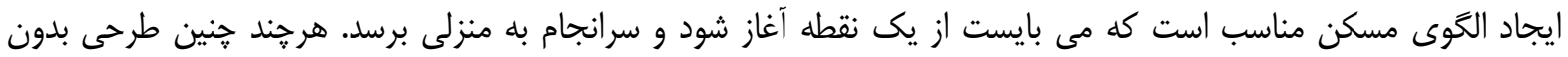
همكارى سازمان هاى مربوطه آن نسبتاً كار سهلى نيست، با اينهمه نظر به شرايط نابسامان مسكن و محيط ييرامون آن اقدام

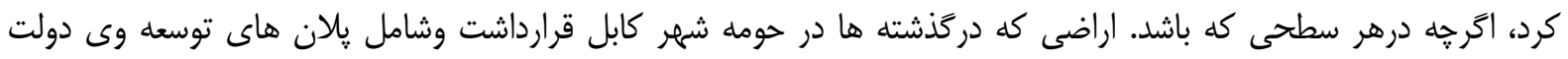

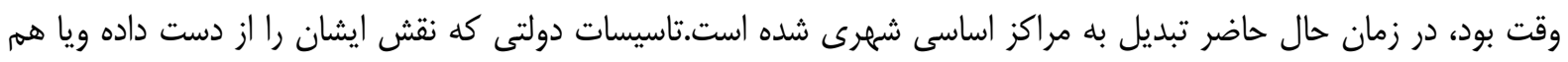

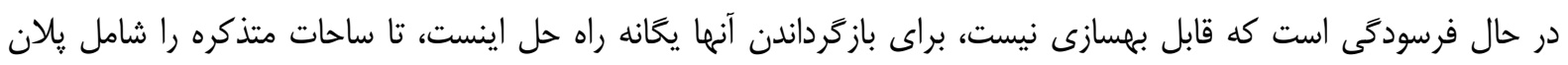

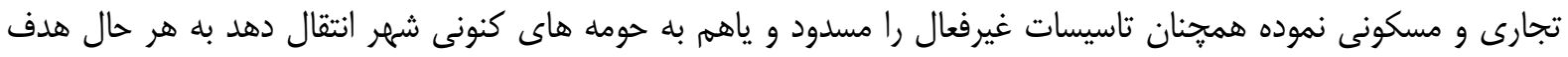
اصلى همان ايجاد يك الكَى مسكن مناسب با ايده حال شرايط كنونى كشور خصوصا شهر كابل(ناحيه سوم شهر كابل، كارته مامورين) است.

\section{هدف از اين تحقيق عبارت است از:}

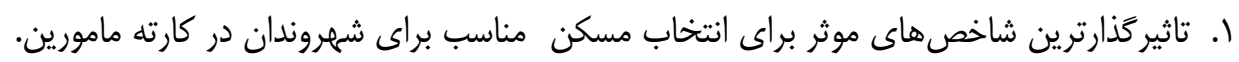
r. معلوم نمودن نوع مسكن مناسب با ارتباط كيفيت ساختمانى و خواسته هاى شهروندان و دسترسى تها.

\section{سئوالات اساسى}

الف)آيا در انتخاب مسكن مناسب براى شهروندان كارته مامورين كدام شاخص تاثير كذار وجود دارد؟ ب) آيا بين شاخص هاى مسكن مناسب از نظر شهرى كه ساختار كالبدى-فضايى شهرى و ساختار محيطى شهرى است كدام

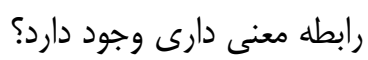

\section{فرضيات يزوهش} فرضيه ا: به نظر ميرسد كه شاخص هاى ساختاركالبدى-فضايى شهرى و ساختار محيطى شهرى در انتخاب مسكن مناسب براى شهروندان كارته مامورين بيشترين تاثير را دارد. فرضيه دومَّ: به نظر ميرسد كه بين شاخص هاى ساختار كالبدى-فضايى شهرى و ساختار محيطى شهرى رابطه معنى دارى 


\section{روش تحقيق}

روش تحقيق در اين يثوهش تحليلى-توصيفى است. براى روش تحقيق كه از نوع كاربرى و تحليلى- توصيفى از روش تحليل سلسله مراتبى (AHP) استفاده مى شود و هم جنان براى آسانى كار و بهتر نتايج بدست آوردن از نرم افزار كمبيوترى كه در

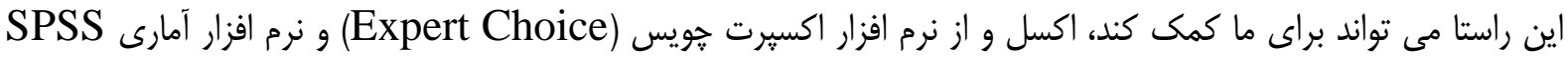

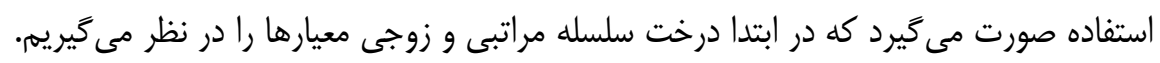

\section{محدوديت هاى تحقيق}

در يزوهش حاضر كه محقق انجام داده است با مشكلات زيادى مواجه بوده است كه اميد است براى محققان آتى اين مشكلات كاسته شود.

عدم كدام معلومات ساختمانى جداكانه درست از كذرهاى جداكانه شهر كابل كه در شهردارىها موجود باشد.

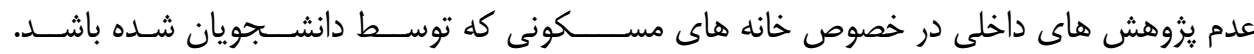
كمبود و ضعف همكارى ادارات مختلف دولتى مخصوصا شهردارى و شهرسازى با محقق در موضوع اطلاعات

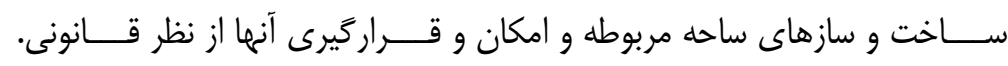
عدم اطلاعات در مورد تراكم جمعيت و غيره در رياست شهردارى مربوطه، بصورت دقيق و مشخص در نواحى مختلف شهر كابل. عدم بودجه تحقيقى ( از طرف دانشخاه، شهردارى، شهرسازى و يا موسسات همكارى كننده شهردارى ها) براى محقق براى تحقيق خويش اســتفاده نمايد.

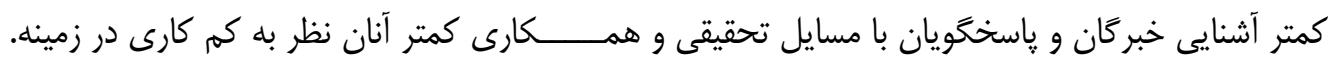
عدم آشنايى مردم محل در موضــوعات تحقيقى براى محصلين و همكارى مـــــــردم در اين موضوع.

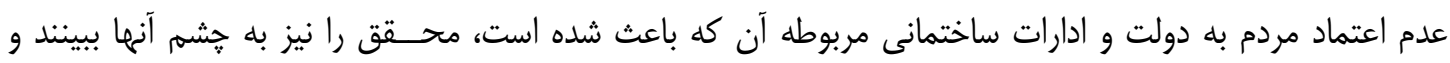

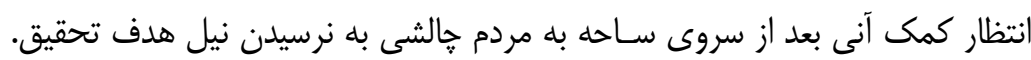

\section{مكان موردى (ناحيه سوم شمر كابل - كارته مأمورين)}

ناحيه سوم شهر كابل از جمله ناحيه هاى كليدى شهر كابل محسوب مى گردد كه بيشترين مراكز آموزشى و دانشخاههاى خصوصى و دولتى را به خود جا داده است. مساحت و حدود اربعه: مساحت اين ناحيه به D,9 كيلومتر مربع مىرسد كه از شرق به يل آرتل، غرب به سرى عمومى سيلو، شمال به كوه تلويزيون، كوه كارته سخى، كوه على آباد و سرك (جاده) باغ بالا و از

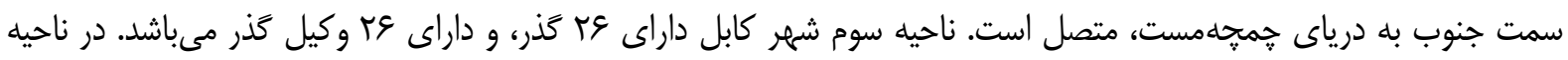

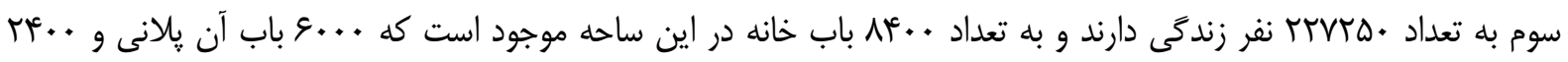
باب آن غيريالى مىباشد. 
نقشه شماره ا، ناحيه سوم شهر كابل، كارته مأمورين.

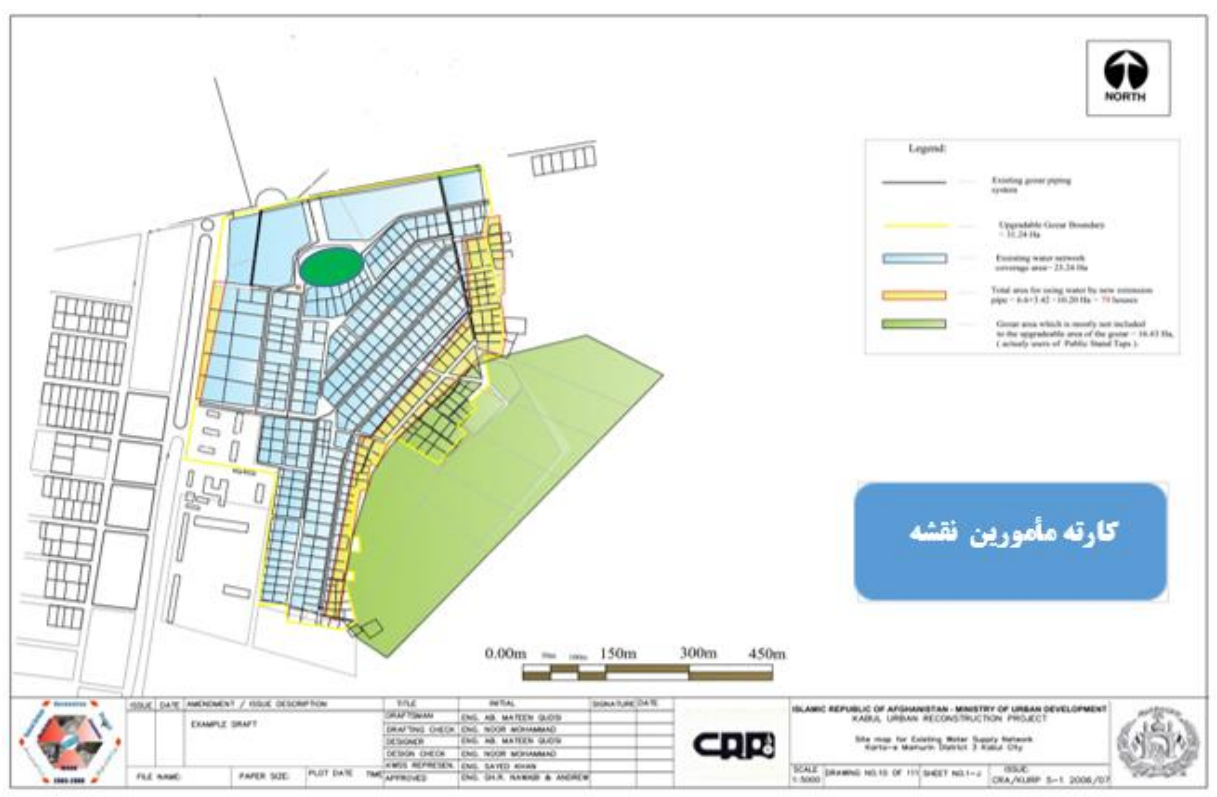

كارته مامورين در نقشه ماستريلان جديد شهر كابل،قسمت هايى را مشخص كرده است كه بطور يلانى ساخته شده است، ولى

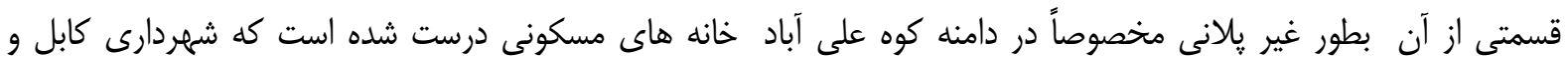
وزارت شهرسازى و اراضى كوشيده است كه خدمات شهرى تاسيساتى را در اين قسمت از خانههاى مسكونى نيز برساند. كذر كارته مامورين به از طرف وزارت شهرسازى و اراضى به • ث خيابان تقسيم شده است كه از خيابان شماره يك الى جهل ام

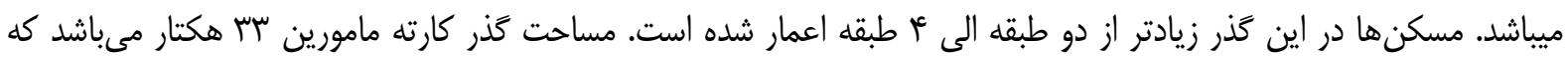

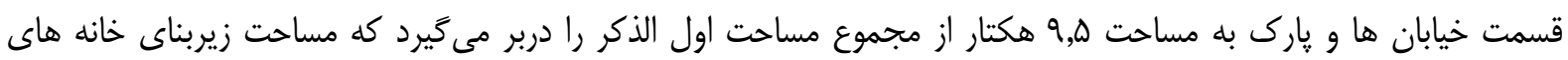
مسكونى و اماكن به ه, بr هكتار مىرسد. جدول شماره : افهرست عمومى اماكن و كاربرى هاى كارته مامورين

\begin{tabular}{|c|c|c|c|}
\hline \multicolumn{4}{|c|}{ فهرست عمومى اماكن و كاربرى هاى كارته مأمورين در ناحيه سوم شهر كابل } \\
\hline تعداد & كاربرى و اماكن & تعداد & كاربرى و اماكن \\
\hline कV & مقازه & r & مسجد \\
\hline ro & 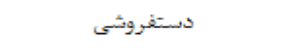 & f & كليـيك درمانى \\
\hline 1 & 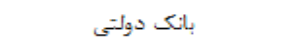 & . & بيمارستان خصوصى \\
\hline$\cdot$ & 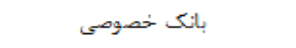 & 9 & دواخانه \\
\hline . & نمابندكى شبكه مخابراتى & $\checkmark$ & كورس هاى آموزشى خصوصى \\
\hline$\cdot$ & 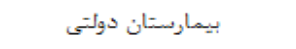 & $\checkmark$ & مكتب (مدرسه) خصوصى \\
\hline ' & مدرسه (حوزه علميه) & r & مكتب (مدرسه) دولتى \\
\hline , & تانك تيل (يمب بنزين) دولتى & $f$ & كودكـــان (مهد كودى) \\
\hline$\checkmark$ & وستورانت & 1 & شبكه آبرسانى دولتى \\
\hline . & هوتل & . & شبكه أبرسانى خصوصى \\
\hline । & محل بازى و تفريح كودكان & r & ماركيت تجارتى كوجِك \\
\hline r & دانشخاه دولتى و خصوصى & $\Delta$ & بلا كى هاى رهابشى \\
\hline ru & دان خاروبار فروشى & 1 & يارى تفريحى \\
\hline$\wedge$ & خياطى & 1 & موسسه تحصيلات نيمه عالى \\
\hline$\Delta$ & كلينيكـ دندان & $f V r$ & خانه رهابشى \\
\hline
\end{tabular}




\section{مبانى نظرى تحقيق}

\section{تعاريف و مفهوم مسكن}

مسكن در حقيقت اسم مكان از ريشه سكن است كه به محل سكون يا توقف كَته مى شود. با اين همه اين وازه مجموعه

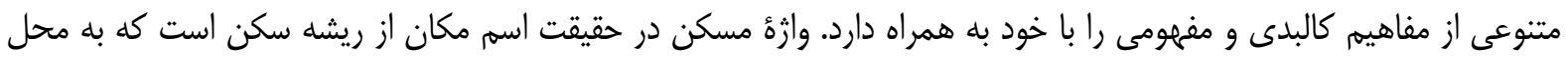

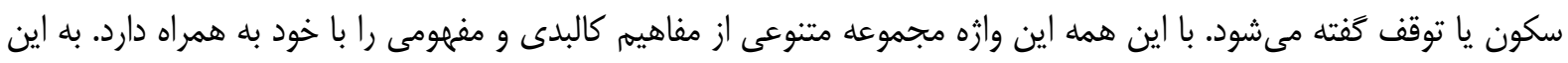
ترتيب در عرصه هاى مختلف جهانى و در دوره هاى مختلف، دسترسى به مسكن يا سريناه مناسب يكى از حقوق و نيازهاى

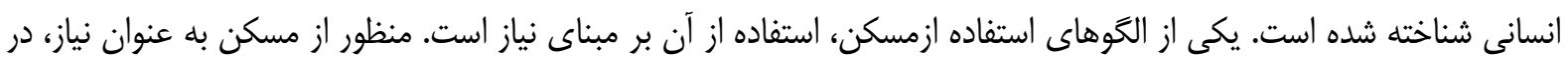
بركيرنده مجموعه اى از نيازهاى انسان است كه ياسخ گوى نيازهاى فيزيولوزيك، روانى و حس تعلق خاطر انسان باشد. مفاهيم

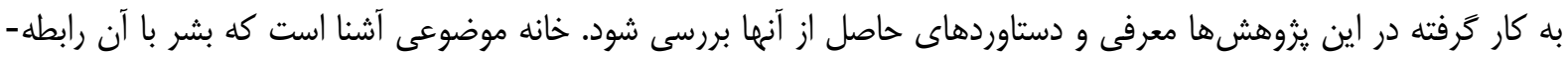

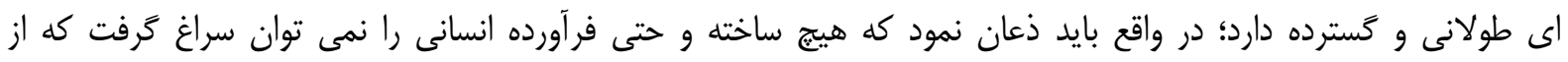

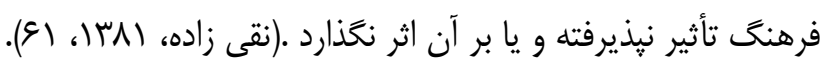

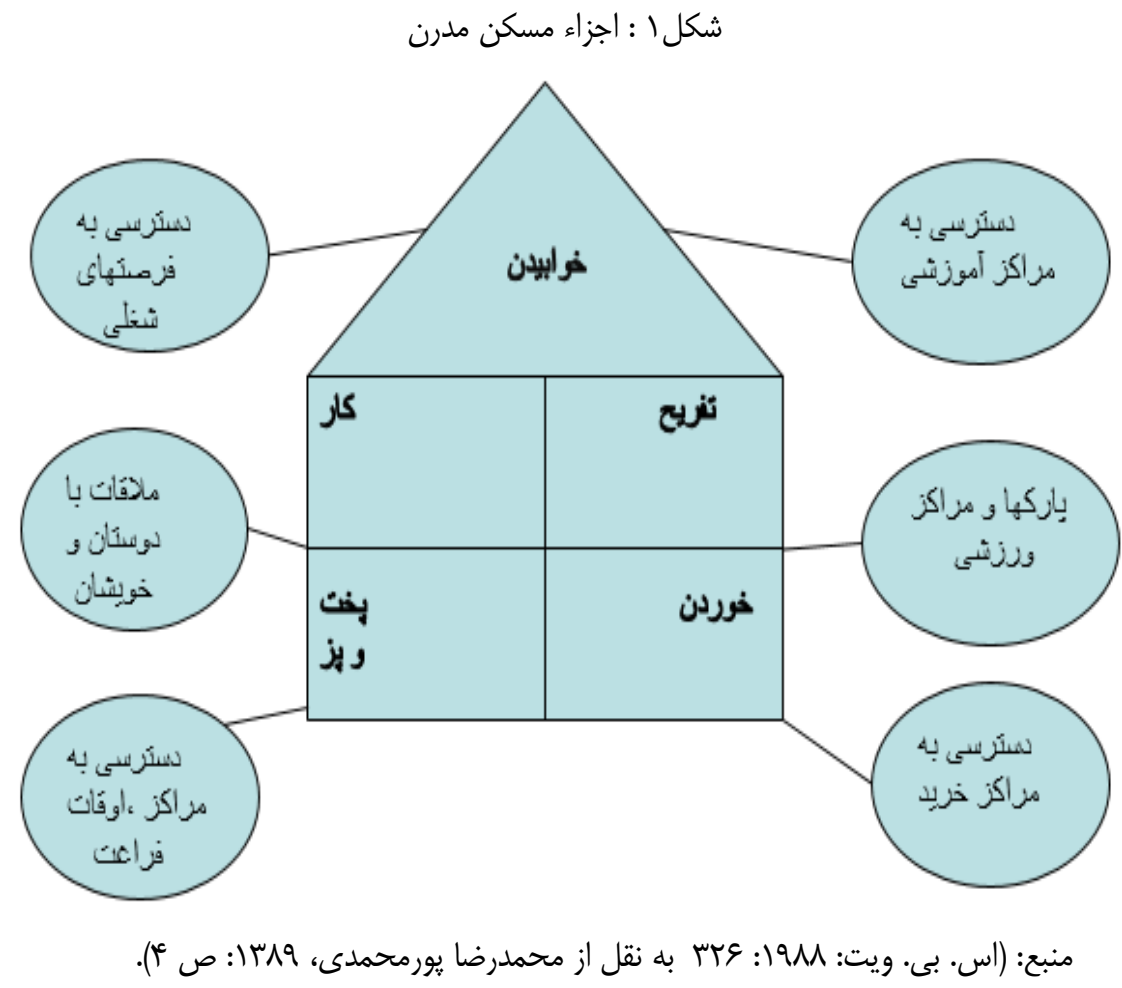

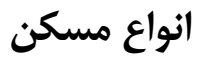

مسكن شهرى از نظر نوع ، تراكم مسكونى و نيز تعداد طبقات و خانوار ساكن به جند دسته طبقهبندى ميشود ، اما از نظر

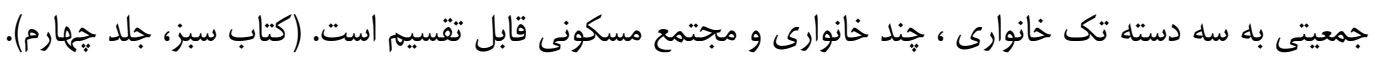

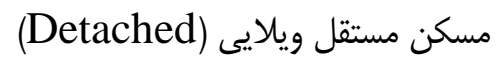

خانه هاى نيمه مستقل (Semi- Detached)

خانه هاى آيارتمانى (Apartment Flats) 
مجتمع هاى مسكونى (Clusters)

برج (Sky Scraper)

تصوير شماره r: وضع موجود تصاحب و غصب يياده راه

تصويرشمارها: ضع موجود راه يله در يياده راه
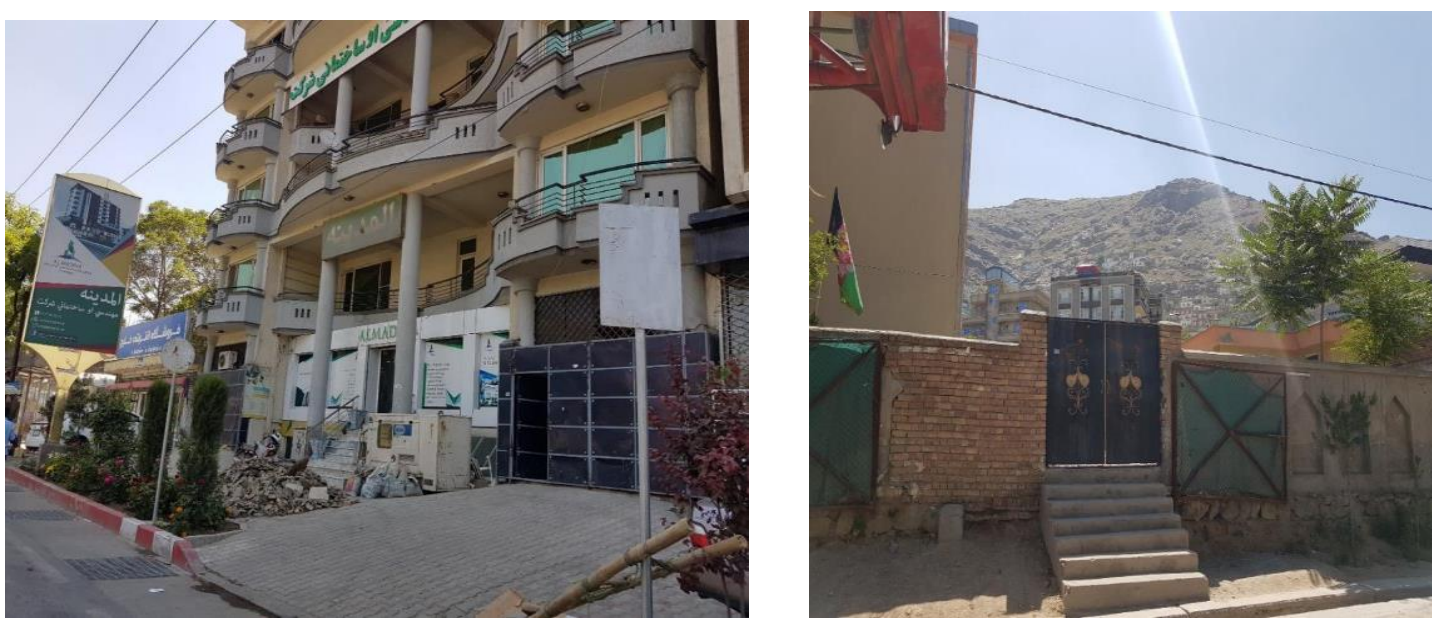

منبع:نغارنده

شاخص هاى مؤثر براى مسكن مناسب با رويكرد تأكيد بر طراحى شهرى

در اين قسمت به بررسى شاخصهاى مؤثر براى مسكن مناسب با درنظرداشت و از موضوع طراحى شهرى در مهرى محدوده كارته مامورين كه مكان مورد مطالعه ما را تشكيل مىدهد مى سيردازيم.

\section{I - شاخص كيفيت كالبدى-فضايى مسكن از نظر طراحى شهرى}

شاخص كيفيت كالبدى- فضايى مسكن از نظر طراحى شهرى از شاخصهاى اساسى در تعيين يك مسكن خوب و مناسب شهرى محسوب مى گردد. به بررسى اين شاخص در ساحه كارته مامورين مىيردازيم كه وجه اول آن به مورد بصرى در ساحه

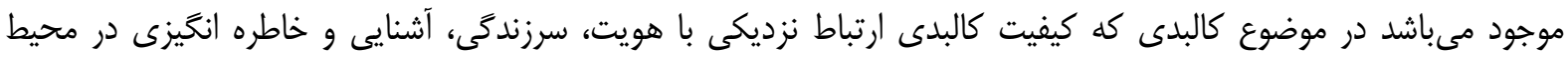
شهرى را دارا مىباشد.

\section{r- شاخص كيفيت ساختارى (از نظرشهرى)}

در اين شاخص در گذر كارته مامورين، موضوعات سازه، مصالح بيرونى ساختمان، تجهيزات، استاندارهاى نخحهدارى و هزينه تعمير مسكن در سطح شهر در خصوص طراحى شهرى را مورد بررسى قرار مىدهيه. براى استحكام بخشيدن به ساخت و سازها ساريا

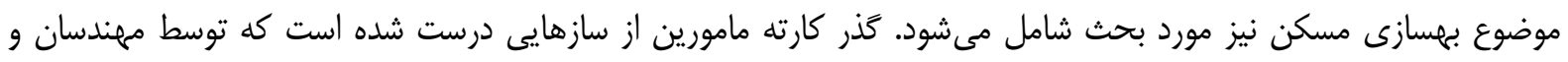
كاركران داخلى اعمار شده است و هر وقت ضرورت به ترميهم و بهسازى ضرورت مهرد نمايد قابل ترميم نيز مىباشند. در مورد استانداردها نيز كمى مراعات شده است ولى در سال هاى اخير موضوع اضافه طبقه اعمار شدن واحدهاى مسكونى و زيادتر شدن سطح اشغال در واحدهاى مسكونى و ضعف شهردارى و شهرسازى در اين موضوعات قابل مشاهده است. 


\section{r - شاخص كيفيت عملكردى (از نظرشهرى)}

طورى كه قبل از آن نيز ذكر گرديده بود شاخص كيفيت عملكردى ساختمانى واحد مسكونى موضوعات مانند: شاخص و نشانه بودن مسكن، نزديك بودن به اماكن مشهور و تاريخى و نامدار، دسترسى خوب و مناسب به ديخر واحدهاى ضرورت مانند

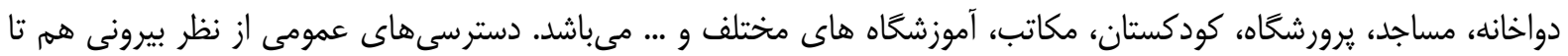

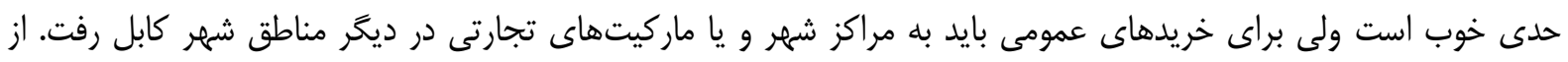

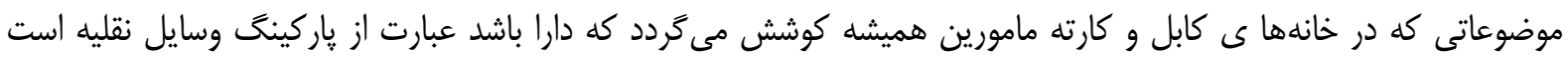
كه حداقل براى يك موتر (ماشين سوارى) كه بايد درنظر گرفت و يا دسترسى به ياركينگ هاى عمومى كه به طور شخصى

\section{ع- شاخص كيفيت محيطى (از نظر شهرى)}

در كذر كارته مامورين كيفيت محيطى مسكن از نظر شهرى كه موضوعات دسترسى ها و امنيت شهرى، تصور ذهنى، تاريخى بودن مكان، ايجاد نقشه هاى دهنى ( كره، لبه، نشانه، تشخيص جهت، موقعيت) و قراركيرى اماكن مسكونى در محيطهاى مناسب از موضوعاتى است كه تاثيركذار بر قيمت زمين و همجنان بر قيمت واحد مسكونى مىتواند كه باشد و اولتر از همه شخصى كه ضرورت به يك واحد مسكونى جه در حالت آيارتمانى يا خانه رهايشى داشته باشد، سوال اول آن موقعيت محيطى و

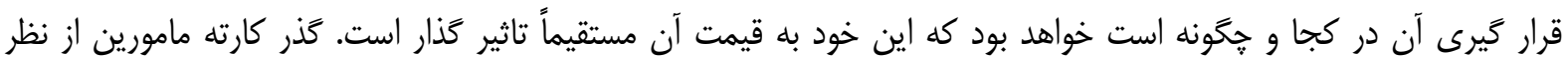
امنيتى تا حدودى بهتر از خيلى جاهاى ديكر شهر كابل مىباشد ولى باز هم ضرورت به به اصلاحاتى دارد كه شرايط امنيت را بيشتر

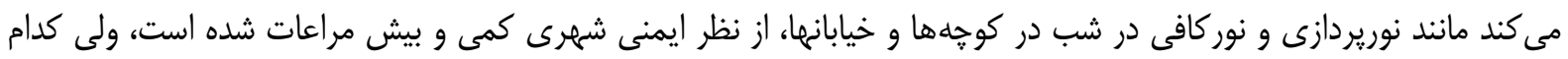
در قسمت مسير ايمنى افراد يياده و سواره ضرورت به اصلاحات زيادى دارد نظير جالى سازى و يا يوشش كامل و كافى كانال هاى دو طرف خيابانها. هم جنان در علامت گذارى نيز كمبودات احساس مى گردد مانند عدم تابلوهاى مشخص نام خيابانها، علايم جهت كذارى شده در مسير سواره و يياده. هم جنان كيفيت محيطى در خيابانها خيلى خشك و بى جان به نظر مىرسد كه عدم سرسبزى و درخت كارى مناسب و كافى در دو طرف خيابانها، عدم كدام سايبان و مبلمان، عدم يباده راه استاندارد مخصوصاً

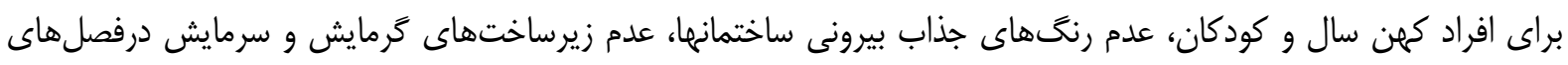
مورد ضرورت بطور همكانى، از موضوعاتى هستند كه در گذر كارته مامورين از نظر بصرى و ذهنى احساس مى گرى دد ديده ميشود

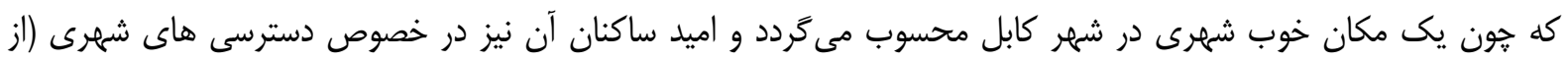
جمله عدم كدام بازارجه كوجى كه مواد غذايى را داشته باشد،رورت احساس مى گَرد) نيز در اين كذر زياد مىباشد بايد توجه وزارت شهرسازى و اركانهاى مربوطه را در اين خصوص بيشتر نمود

\section{ه-شاخص كيفيت مربوط به نيازهاى انسان از نظرشهرى}

از نيازهاى اوليه براى انسانها سريناه و مسكن است و اين مسكن بايد كه نيازهاى انسانها را با كيفيت مطلوب و كافى آن جوابخو باشد ولى جون انسان يك موجود اجتماعى مىباشد، ضرورت احساس مى و خدمات شهرى و دسترسى ها اين زمينه را براى انسانها مهيا مى سازد كه انسان ها بتوانند با هم در ارتباط باشند و نيازهاى بـاى

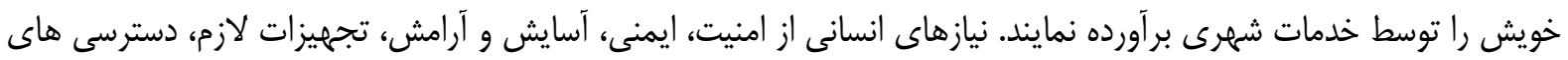

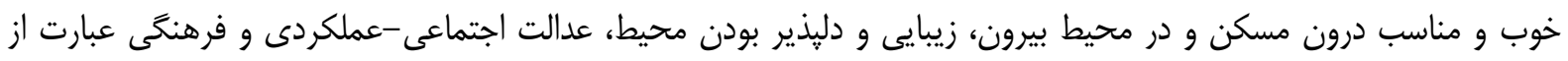
موضوعاتى است كه نيازهاى عمومى انسانها را براى يك سريناه و مسكن در محيط شهرى را بايد داشته باشد. كذركارته 
مامورين از نظر موضوعات فوق الذكر بطور عمومى به بررسى درنظر مى گيريم با درنظرداشت ضعف اقتصادى و مشكل مسكن به آن تن داده شده است.

\section{تجزيه و تحليل}

در قدم اول به تشكيل نمودار درخت سلسله مراتبى اقدام خواهد شد. كه از روى اين درخت سلسله مراتبى معلوم مى گردد كه

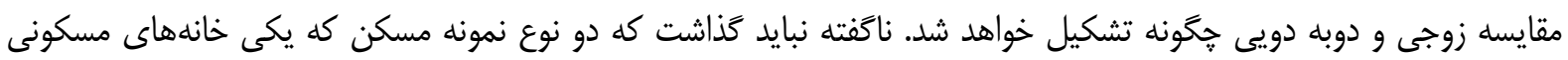
حويلى دار (حياط) و ديخرى كه بلاكهاى رهايشى -مسكونى مىباشد كه در ساحه مورد مطالعه همين دو نوع مسكن مىباشد در قسمت انتخاب گزينه درنظر گرفته خواهد شد.

نمودار ז: نمودار درخت سلسله مراتبى براى انتخاب گزينه هاى ييشنهادى و مقايسه دو دويى

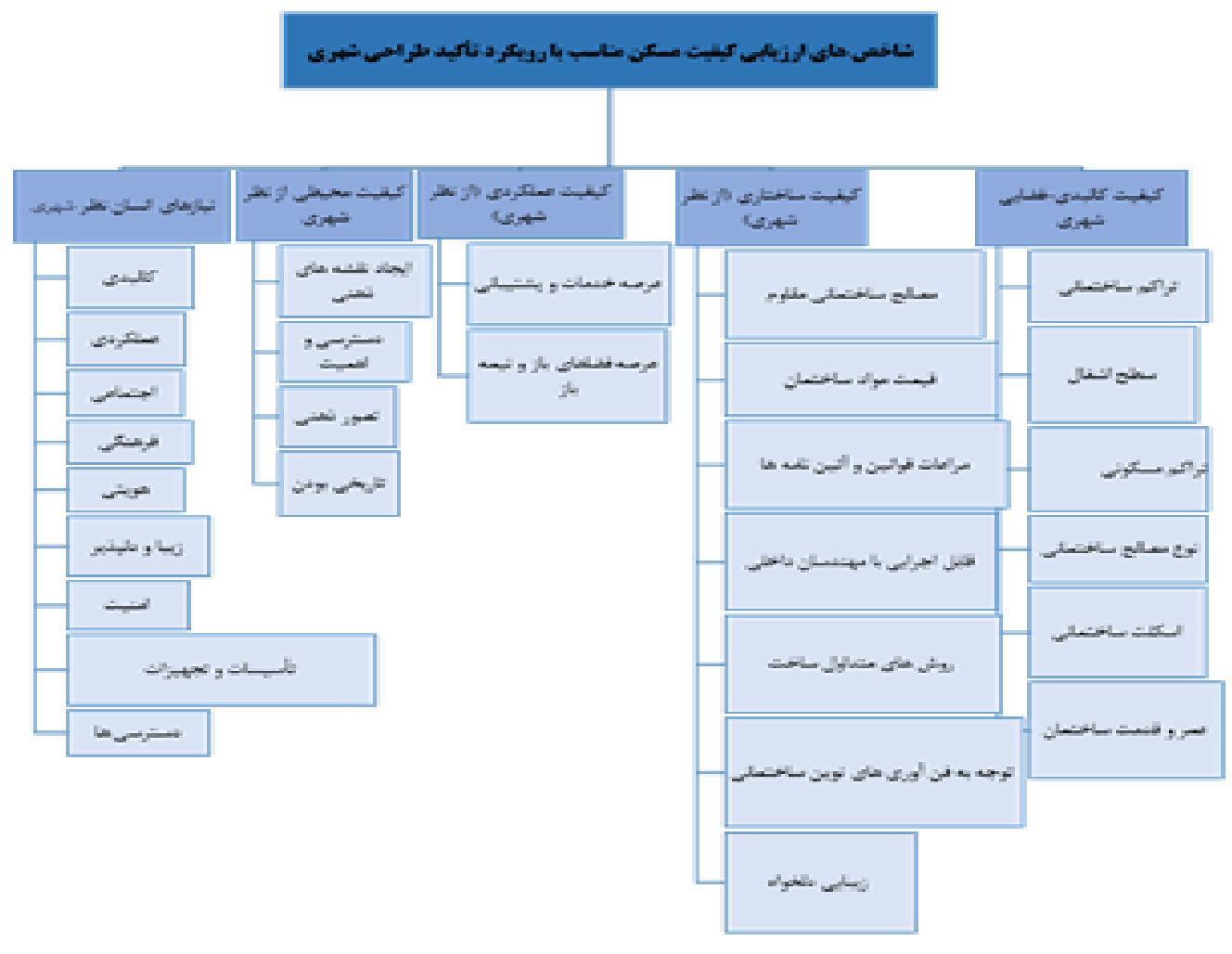

منبع:نغارنده

بررسى فرضيه هاى تحقيق

جدول شماره ז: آزمون KMO

\begin{tabular}{|c|c|c|}
\hline \multicolumn{3}{|c|}{ KMO and Bartlett's Test } \\
\hline Kaiser-Meyer-Olkin Measure of Sampling Adequacy. & .774 \\
\hline Bartlett's Test of Sphericity & Approx. Chi-Square & 531.223 \\
\hline \multirow{3}{*}{ Bartlett's Test of Sphericity } & Approx. Chi-Square & 531.223 \\
\cline { 2 - 3 } & Df & 6 \\
\cline { 2 - 3 } & Sig. & .000 \\
\hline
\end{tabular}


جدول شماره بّ: آمار استخراجى آزمون KMO

\begin{tabular}{|c|c|c|}
\hline \multicolumn{3}{|c|}{ Communalities } \\
\hline & Initial & Extraction \\
\hline متغير ساختار كالبدى-فضايى شهرى متغير كيفيت عملكردى از نظر شهرى 1.000 & .662 \\
\hline متغير كيفيت ساختارى ساختار محيطى شهرى & 1.000 & .559 \\
\hline \multicolumn{3}{|c|}{ Extraction Method: Principal Component Analysis. } \\
\hline
\end{tabular}

طورى كه در جدول فوق ديده مىشود، شاخص KMO بيشتر از ه, · مىباشد كه در حد قابل قبول مىباشد بلكه و هم جنان بيشتر از V,• كه حالت خوب را نشان مىدهد و تعداد يرسشنامهاى ما نظر تعداد سوالات ما خيلى خوب است و شاخص

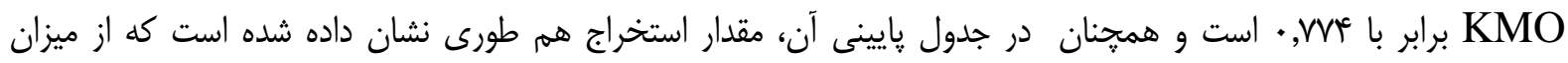
خوبى در توزيع بين شان برخوردار مىباشد.

جدول شماره \& : بيشترين مقدار استخراج و وريانس

\begin{tabular}{|c|c|c|c|c|c|c|}
\hline \multicolumn{7}{|c|}{ Total Variance Explained } \\
\hline \multirow{2}{*}{$\begin{array}{c}\text { Co } \\
\text { mpo } \\
\text { nent }\end{array}$} & \multicolumn{3}{|c|}{$\begin{array}{c}\text { Initial } \\
\text { Eigenvalues }\end{array}$} & \multicolumn{3}{|c|}{$\begin{array}{c}\text { Extraction Sums } \\
\text { of Squared } \\
\text { Loadings }\end{array}$} \\
\hline & $\begin{array}{c}\text { Tot } \\
\text { al }\end{array}$ & \begin{tabular}{|c|}
$\%$ of \\
Varia \\
nce
\end{tabular} & \begin{tabular}{|c|} 
Cum \\
ulativ \\
e $\%$
\end{tabular} & $\begin{array}{l}\text { Tot } \\
\text { al }\end{array}$ & $\begin{array}{c}\% \text { of } \\
\text { Varia } \\
\text { nce }\end{array}$ & $\begin{array}{c}\text { Cum } \\
\text { ulativ } \\
\text { e \% }\end{array}$ \\
\hline 1 & 2.64 & 66.16 & 66.16 & 2.64 & 66.16 & 66.16 \\
\hline 1 & 7 & 8 & 8 & 7 & 8 & 8 \\
\hline 2 & .591 & $\begin{array}{c}14.76 \\
5\end{array}$ & \begin{tabular}{|c|}
80.93 \\
3 \\
\end{tabular} & & & \\
\hline 3 & .482 & $\begin{array}{c}12.05 \\
7\end{array}$ & $\begin{array}{c}92.99 \\
0\end{array}$ & & & \\
\hline 4 & .280 & 7.010 & $\begin{array}{c}100.0 \\
00\end{array}$ & & & \\
\hline & & पet & od: $F$ & 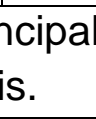 & & en \\
\hline
\end{tabular}

بر سرى فرضيه اول

" به نظر مىرسد كه معيارهاى ساختاركالبدى-فضايى شهرى و ساختار محيطى شهرى در انتخاب مسكن مناسب براى شهروندان كارته مامورين بيشترين تاثير را دارد." معيد 
جدول شماره ه: خلاصه نمونه كل تنوع وريانس

\begin{tabular}{|c|c|c|c|c|}
\hline \multicolumn{5}{|c|}{ Model Summary } \\
\hline Model & R & $\begin{array}{c}\mathrm{R} \\
\text { Square }\end{array}$ & $\begin{array}{c}\text { Adjusted R } \\
\text { Square }\end{array}$ & $\begin{array}{l}\text { Std. Error of } \\
\text { the Estimate }\end{array}$ \\
\hline 1 & .819 & .671 & .682 & .02103 \\
\hline ساختار & ,متغير & 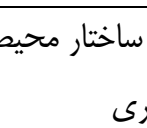 & كالبدى-فضايى :a. Predict & (Constant), \\
\hline
\end{tabular}

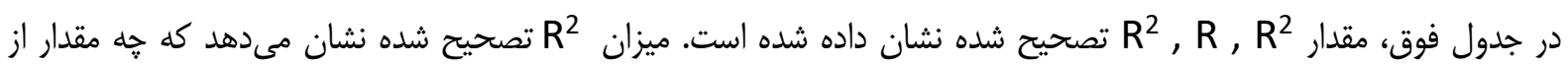
كل تنوع (واريانس) متغير مسكن مناسب از نظر طراحى شهرى را توسط دو متغير ساختار محيطى شهرى و ساختار كالبدى - مانس

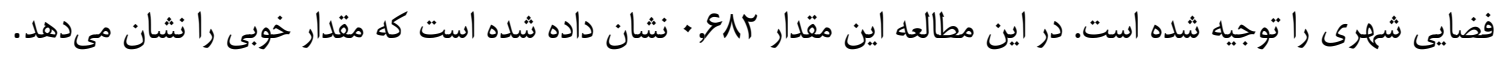

\section{بر رسى فرضيه دوم}

" به نظر مىرسد كه بين معيارهاى ساختار كالبدى فضايى شهرى و ساختار محيطى شهرى رابطه معنى دارى وجود دارد." براى فرضيه دوم تحقيق از آزمون همبستخى غيريار امتريك اسيرمن استفاده مىنمائيم.

جدول شماره 9: بررسى همبستى بين متغيرهاى ساختار كالبدى-فضايى شهرى و ساختار محيط شهرى

\begin{tabular}{|c|c|c|c|c|}
\hline \multicolumn{5}{|c|}{ Correlations } \\
\hline & & & 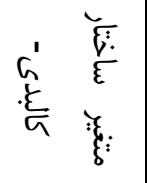 & 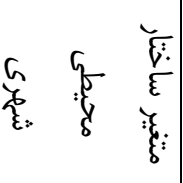 \\
\hline \multirow{6}{*}{ 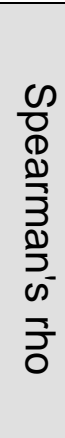 } & \multirow{3}{*}{ 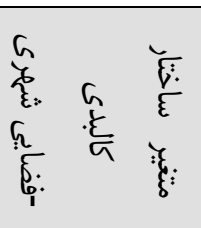 } & $\begin{array}{l}\text { Correlation } \\
\text { Coefficient }\end{array}$ & 1.000 & $.782^{* *}$ \\
\hline & & Sig. (2-tailed) & & .000 \\
\hline & & $\mathrm{N}$ & 345 & 345 \\
\hline & \multirow{3}{*}{ 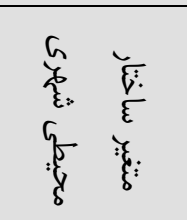 } & $\begin{array}{l}\text { Correlation } \\
\text { Coefficient }\end{array}$ & $.782^{* *}$ & 1.000 \\
\hline & & Sig. (2-tailed) & .000 & . \\
\hline & & $\mathrm{N}$ & 345 & 345 \\
\hline
\end{tabular}

نظر به جدول فوق ديده مىشود كه مقدار P Value يا همان مقدار Sig از ه.,. كمتر مى باشد و اين به معنى اصلى رابطه معنى دارى داشتن بين دو متغير تحقيق كه درفوق ذكر كرديده است مى باشاشد. 


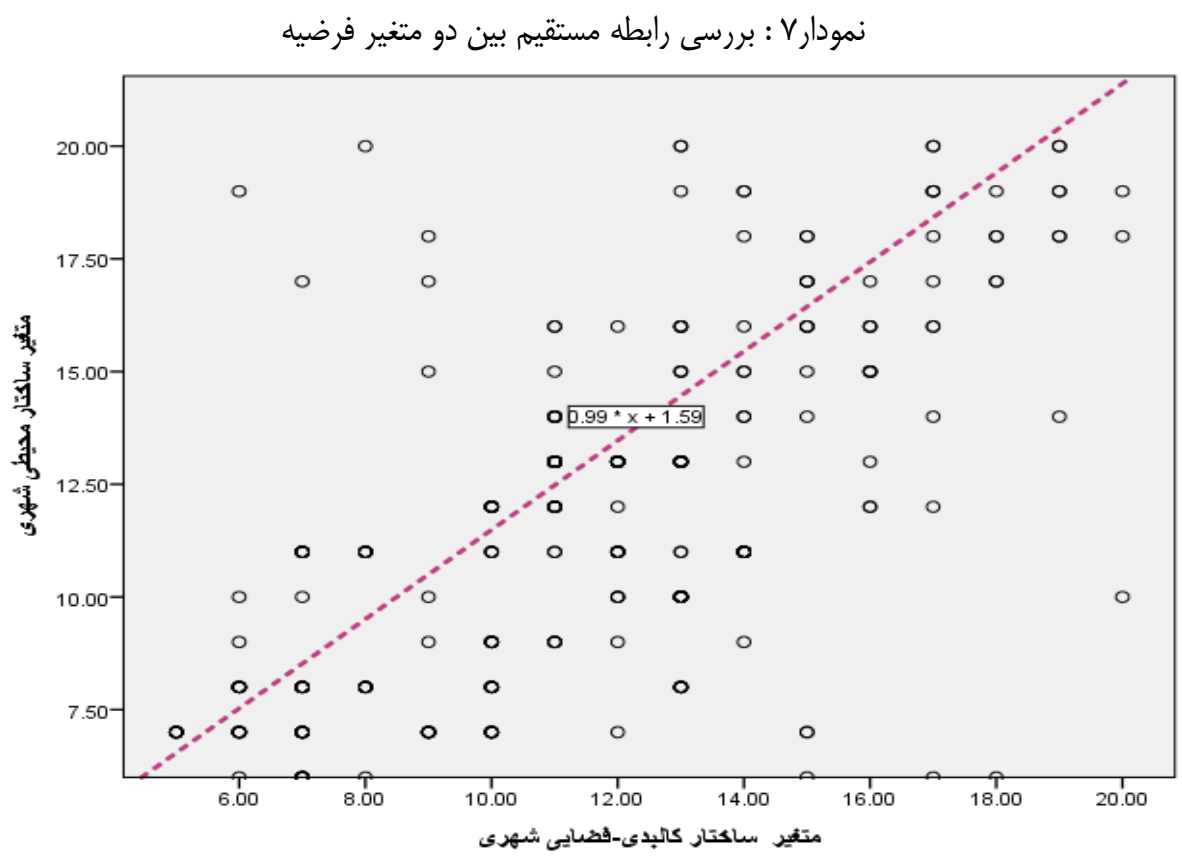

نتيجه كَيرى

در اين قسمت به نتيجه كيرى كه از تجزيه و تحليل داده دست يافتهايم مىيردازيه. در قسمت تجزيه و تحليل مقايسه زوجى يافتيم كه كدام معيارها اصلى در اولويت قرار دارد و بهتر به نظر رسيده است و يا هم توجه بيشتر شده است كه در نمودار يايين

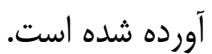

نمودار شماره ا: اولويت بندى برحسب مسكن مناسب

Priorities with respect to:

Goal: الكوبابى مسكن مناسب نطر به طراحى شهر

ساخنار كالبدى-فضايى شهرى

ساختار محبطى شهرى

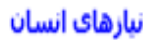

كبفيت عملكردى إز نطر شهرى كبفيت ساختارى عملكري

= 0.04

With 0 missing judgments.

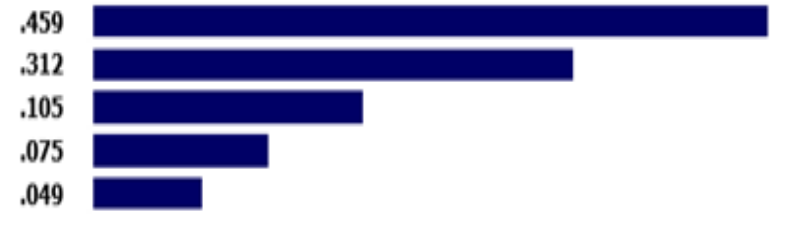

نتيجه نهايى براى يك الخوى مسكن مناسب از نظر طراحى شهرى براى كارته مامورين بيشترى اهميت را داشتن معيار و شاخص ساختار كالبدى -فضايى شهرى دارا مىباشد. كه اين شاخص داراى زير شاخص ها و موضوعات جون: دسترسى خوب و مناسب مسكن مناسب به خدمات شهرى نظير درمانگاه، كودكستان، مكاتب و آموزشگاه هاى مختلف، يارى و محيط سبز و تفريحى سرباز، آب و برق، ارتباط خوب و مناسب از نظر اتصال خيابانهاى فرعى به خيابانهاى اصلى، دسترسى آسان به وسايط نقليه شهرى، ارتباط خوب و ييوستخى مناسب مسيرهاى سواره و پياده، پاركينگ هاى عمومى و يا هم شخصى، شاخص و نشانه بودن مكان در صورت آدرس دهى نظير مكان يابى براى افراد و يا هم خدمات رسانى، محيط و فضاى كالبدى شهرى آرام از 
سروصداى هاى مزاحم، دسترسى به اماكن تفريحى مختلف براى اقشار مختلف جامعل، عارى از گردوخاك محيط كه از فضاى محيط مناسب برخوردار باشد كه اين موضوع به قسمت موضوعات شرايط محيطى مناسب مىتوان يادآور شد مى باشد كه در قدم

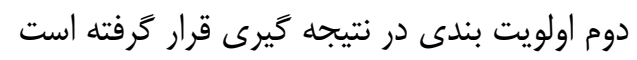

\section{ي بيشنهادات}

در موردالكوى مسكن مناسب از نظر طراحى شهرى ييشنهادات ذيل از نظر محقق حايز اهميت شمرده شده است كه به آنها

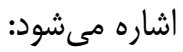

ايجاد يك قانون نظام مهندسى خوب با اركان مربوطه آن و تطبيق آن در سراسر كشور، و صلاحيت امتياز براى نقشه دهى و تطبيق براى مهندسان و انجينرانى كه اين آزمون مهندسى را جواز كار و فعاليت اش را داشته باشند مخصوصا در امور مسكن. مسكن مناسب بايد داراى تمامى معيارهاى اصلى كه در يثوهش به آنها اشاره شده است را دارا باشد و يا تا حد زيادى آنها را يوشش داده بتواند، باشد علاقه مردم بيشتر به خانههاى مسكونى حويلى دار (حياط) ديده مى شود، شهردارى و شهرسازى در خانه هاى رهايشى

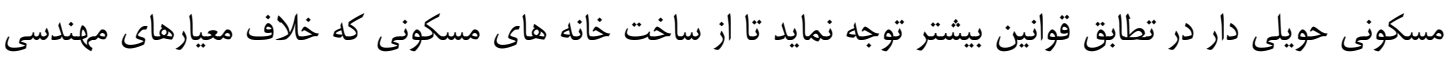
مىباشند را تا حد امكان جلوگيرى صورت كيرد. از دانش بيرونى و درونى كشور براى سطح ارتقا مساكن در كشور مخصوصا در شهرها توجه شود.

\section{فهرست منابع فارسى:}

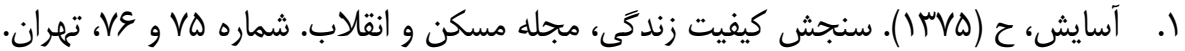
ז. اكبرى، د ـ بررسى تطبيقى دو الكوى مجتمع هاى مسكونى (متعارف و بلندمرتبه). نشريهى هنرهاى زيبا، دانشخاه تهران، شماره Tr،

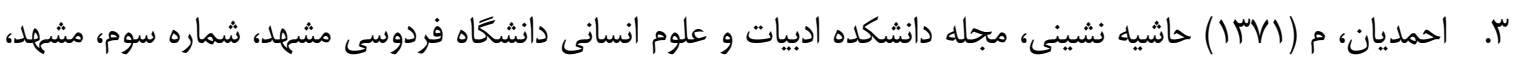
صص (19-19-19. F. اهريف ز و ارجمندنيا، | (••rrا). مسكن حداقل، مركز تحقيقات ساختمان و مسكن، تهران.

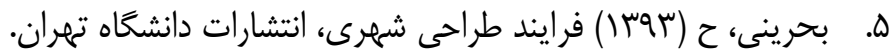

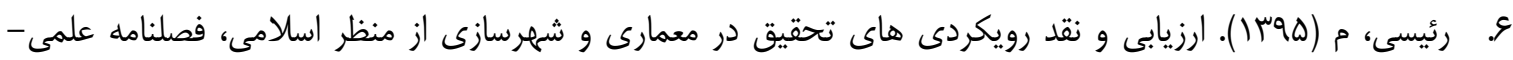

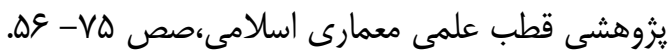
V. باتمانى، ك. نقش فضاى عمومى ونيمه عمومى در مسكن مهر با هدف ارتقا كيفيت زندگى اجتماعى كاربران، نمونه

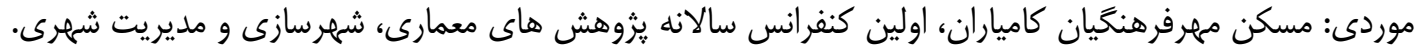

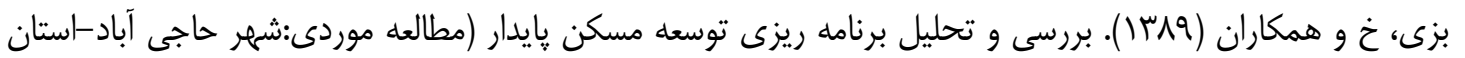

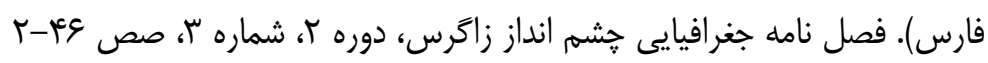

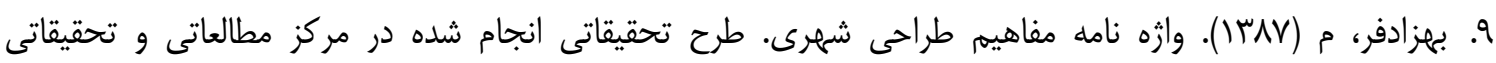

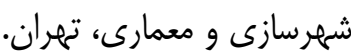




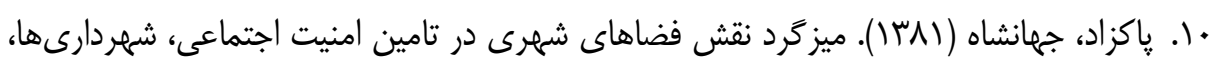
II

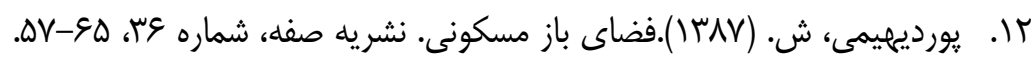

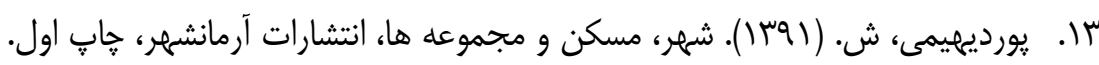

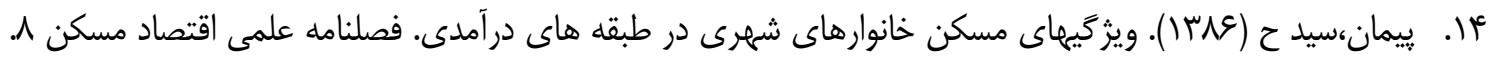

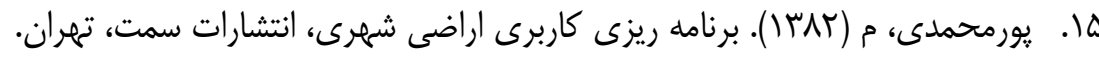

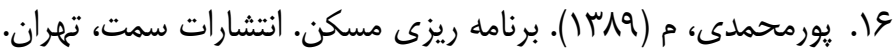

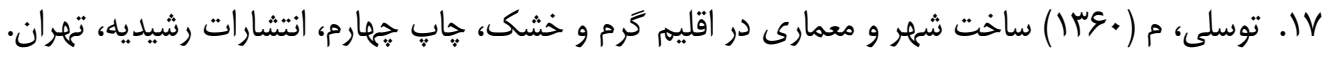

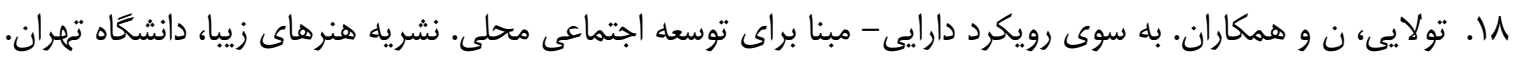

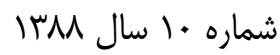
19. حافظ نيا، م رضا. (هوس(1). مقدمه اى بر روش تحقيق در علوم انسانى، ( تجديد نظز اساسى با اضافات)، تهران: انتشارات سمت. •r. حسينى، س ضياء. (rqس (). مقدمه اى بر تاريخ معمارى و شهرسازى افغانستان:انتشارات خراسان، كابل.

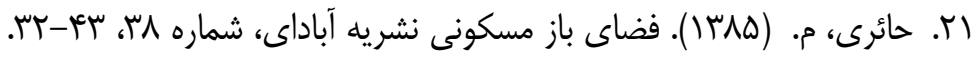

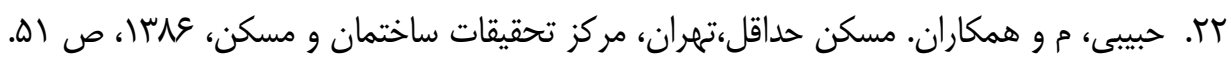

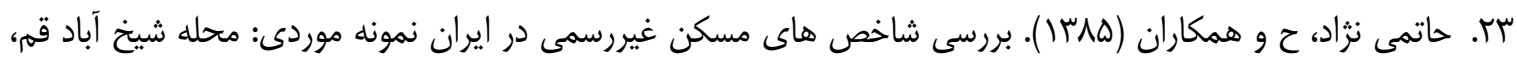

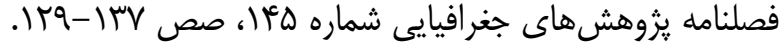

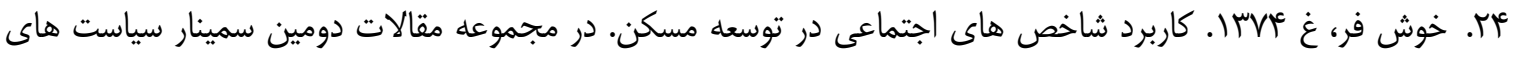

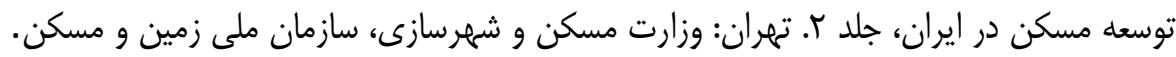

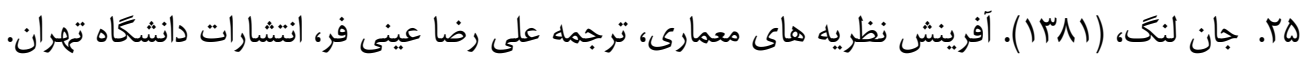

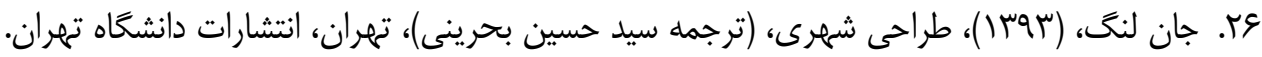

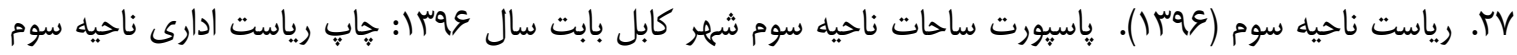
شهردارى كابل.

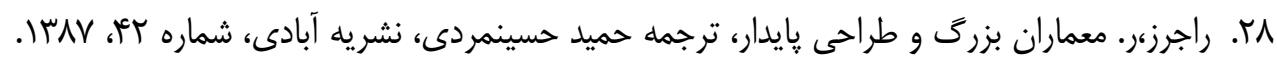

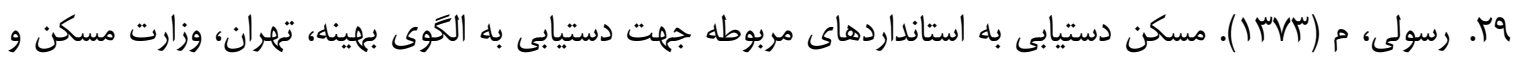

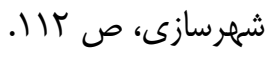
•". رضايى، م (اوسا). ارزيابى ميزان رضايتمندى ساكن از مجتمع هاى مسكن مهر، فصلنامه علمى و يثوهشى مطالعات شهرى، شماره ينجمه.

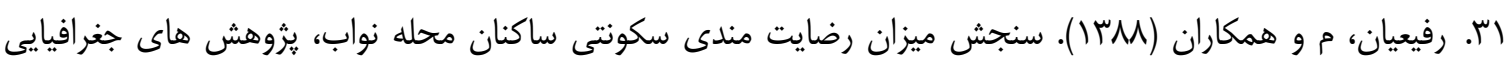

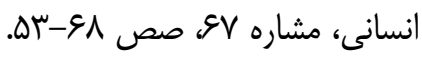

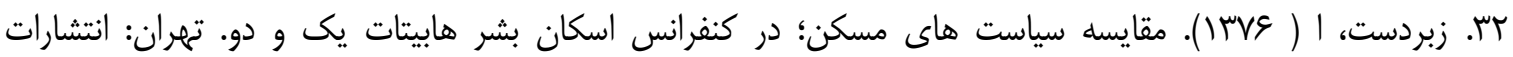

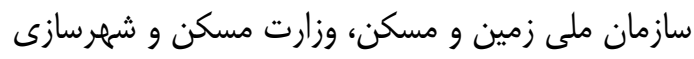

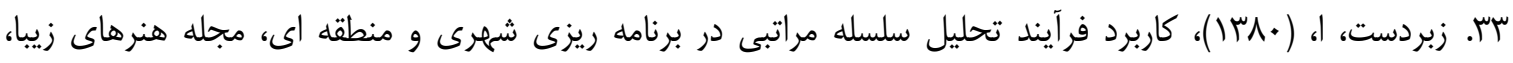
شماره +1، دانشعاه تهران.

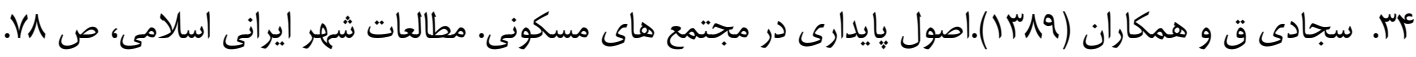

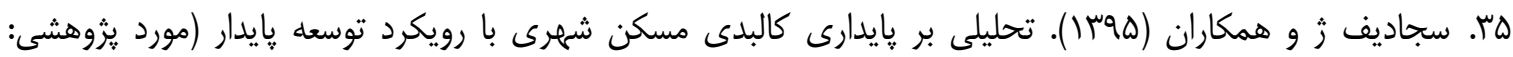

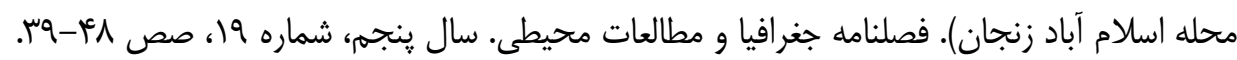




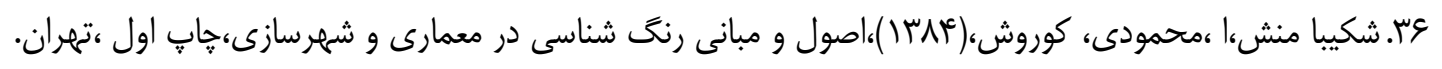

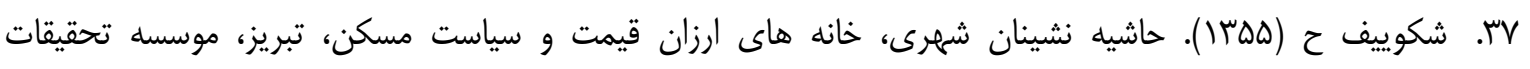

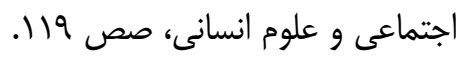

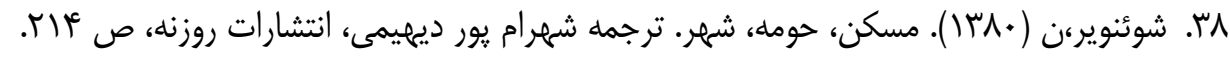

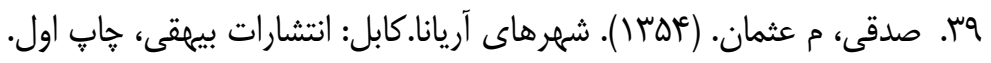

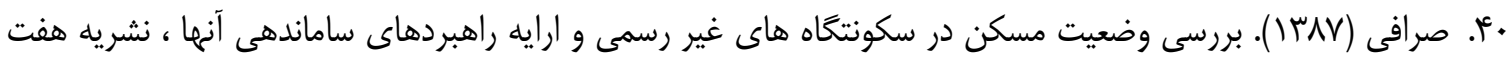

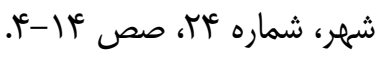

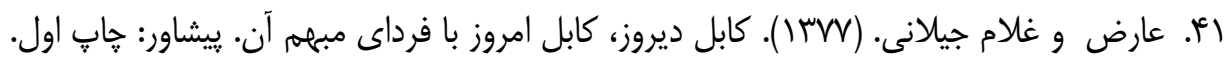

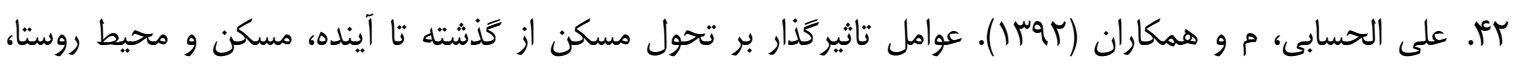
شماره أli.

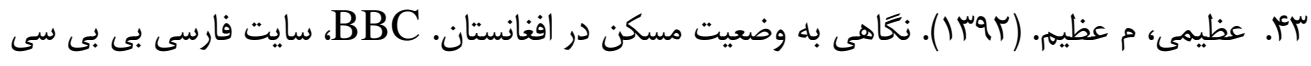

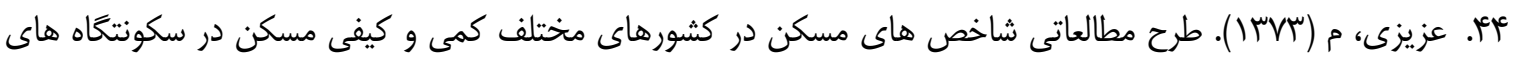

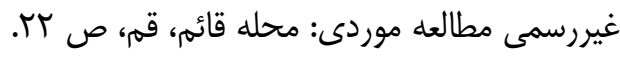

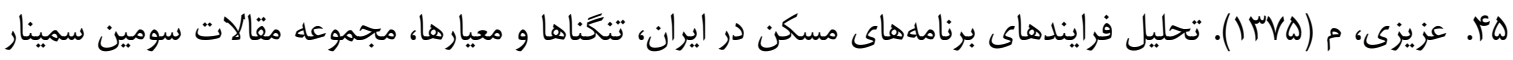
سياست هاى توسعه مسكن در ايران، وزارت شهرسازى و مسكن.

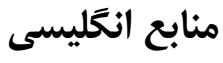

1. Abdul Ghani, S., \& Noraini, Y. (2006). residential satisfaction in low-cost housing in malaysia. report of research. funded by USM short term research .grant.

2. Akhter, A.M. \& Toran, K. (2004) migration, slums \& urban squalor, proceedings of the third international conference on environment and health,1517 December, Chennai, India, 123.

3. Ahari, Zahra, \& Shahla Amini Jadid( 1996) The Experiences of Different Countries In Housing. Tehran: National Land and Housing.

4. Amerigo, M., \& Aragones, J. (1997). a Theoretical and Methodological Approach To The Study Of Residential Satisfaction. Journal of Environmental .Psychology, vol. 17, no.

5. Australian Capital Territory Government. (2000)Crime Prevention And Urban Design Resource Manual Department Of Urban Services. Australian, Sarkissian .Associates Planners in collaboration with ACT Planning Land Management.

6. Beiti, Hamed. 2010. The Role of the Yard in Organizing the Historic Houses: A Case Study House of Tabriz Qajar Period. Ketabmah(Honar) 149: 58-64.

7. Cabrita, A. R., Freitas, M. J., \& Pedro, J. B. (1998 Understanding Housing Satisfaction. XXV IAHS World Housing Congress, engineering faculty of the University of Porto, Portugal.

8. Joseph, J. D. and H. Vincent. (2001). "Mayor Bill de Blasio's Affordable Housing Plan Faces Roadblocks". Wall Street Journal.

9. Kuo et al., 1998 F.E. Kuo, W.C. Sullivan and A. Wiley, Fertile ground for community:" inner-city neighbourhood common spaces", American Journal of Community Psychology 26 (1998), pp. 823-851. 
10. Ruiz-Tagle, J. (2013). A theory of socio-spatial integration. International Journal of Urban and .Regional Research, 37(2), 388-408

11. United Nations Human Settlements Program (UN-Habitat) (2012). Sustainable Housing for Sustainable Cities: A Policy Framework for Developing Countries.

12. Ulack, R. (2014), The role of urban squatter settlement, annals of the association of American geographers, vol. 68, no. 4, 535-550

13. Wicker, Allen W. (1984);" An Introduction to Ecological Psychology"; New York: Cambridge University Press.

14.-Maliene, V., \& Malys, N (2009). Highquality housing-A key issue in delivering sustainable communities. Building and Environment, 44(2), 426-430. 